\title{
KOMPARASI AKTIVITAS BELAJAR GEOGRAFI ANTARA SISWA KELAS XI KELOMPOK PEMINATAN DENGAN KELOMPOK LINTAS MINAT DI SMA NEGERI 2 PADANG
}

\author{
Ramadanis. J \\ Program Studi Pendidikan Geografi \\ FIS Universitas Negeri Padang \\ Email: Ramadanis13@gmail.com
}

\begin{abstract}
Abstrak
Penelitian ini bertujuan untuk (1) mengetahui aktivitas belajar geografi siswa kelas XI kelompok peminatan di SMA N 2 Padang, (2) mengetahui aktivitas belajar geografi siswa kelas XI kelompok lintas minat di SMA N 2 Padang, (3) mengetahui perbandingan aktivitas belajar geografi antara siswa kelas XI kelompok peminatan dengan lintas minat di SMA N 2 Padang. Jenis penelitian ini adalah penelitian deskriptif dengan pendekatan kuantitatif. Hasil penelitian menunjukkan bahwa (1) aktivitas belajar geografi siswa kelas XI kelompok peminatan di SMA N 2 Padang terdapat $33.33 \%$ siswa aktif, $40.00 \%$ siswa cukup aktif, $6.67 \%$ siswa kurang aktif, dan tidak ada siswa sangat aktif. (2) aktivitas belajar geografi siswa kelas XI kelompok lintas minat di SMA N 2 Padang terdapat $17.14 \%$ siswa sangat aktif, $62.86 \%$ siswa aktif, $20.00 \%$ siswa cukup aktif, dan tidak ada siswa kurang aktif. (3) perbandingan aktivitas belajar geografi siswa kelas XI kelompok peminatan dengan lintas minat di SMA N 2 Padang yaitu siswa kelas XI kelompok peminatan memiliki aktivitas belajar geografi yang rendah dari pada siswa kelas XI kelompok lintas minat di SMA Negeri 2 Padang.
\end{abstract}

Kata Kunci: Aktivitas Belajar Geografi, Kelompok Peminatan dan Lintas Minat

\begin{abstract}
The purpose of this research are (1) to find out students activity of learning geography class XI interest group in SMA N 2 Padang. (2) to find out students activity of learning geography class XI cross-interest group in SMA N 2 Padang. (3) to find out the comparison of the activity of learning geography between group interest and cross-interest in SMA N 2 Padang. This is qualitative reserach with quantitative approach. The results of the reserach show that (1) students activity of learning geaography class XI interest group in SMA N 2 Padang consist of 33.33\% students are active, $40.00 \%$ students are quite active, $6.67 \%$ students are less active, and none of students are very active. (2) students activity of learning geography class XI cross-interest group in SMA N 2 Padang consist of $17.14 \%$ students are very active, $62.86 \%$ students are active, $20.00 \%$ students are quite active and none of students are less active. (3) The comparison between students activity of learning geography class XI interest group and cross-interest group in SMA N 2 Padang show that students of class XI interest group have low activity of learning geography from students of class XI cross-interest group in SMA N 2 Padang.
\end{abstract}

Key words: Geography Learning Activity, Interest Group, and Cross-Interest

\footnotetext{
${ }^{1}$ Mahasiswa Program Studi Pendidikan Geografi untuk Wisuda Maret 2018
} 
PENDAHULUAN

Pembelajaran adalah suatu aktivitas yang berlangsung dalam interaksi aktif dengan lingkungan, yang menghasilkan perubahan-perubahan dalam pengetahuan, pemahaman, keterampilan, nilai dan sikap. Dalam Undang-undang Nomor 20 tahun 2003 tentang Sistem Pendidikan Nasional Pasal 1 Ayat 20 dinyatakan bahwa "Pembelajaran adalah proses interaksi peserta didik dengan pendidik dan sumber belajar pada suatu lingkungan belajar".

Kemudian Permendikbud nomor 22 tahun 2016 tentang Standar Proses Pendidikan Dasar dan Menengah bahwa "Proses pembelajaran pada satuan pendidikan diselenggarakan secara interaktif, inspiratif, menyenangkan, menantang, memotivasi peserta didik untuk berpartisipasi aktif, serta memberikan ruang yang cukup bagi prakarsa, kreativitas, dan kemandirian sesuai dengan bakat, minat, dan perkembangan fisik serta psikologis peserta didik".

Dalam proses pendidikan yang ada di sekolah, kegiatan pembelajaran merupakan kegiatan yang paling pokok, berarti berhasil tidaknya pencapaian tujuan pendidikan tergantung pada proses pembelajaran yang dialami oleh siswa sebagai peserta didik. Menurut Pribadi (2011:6) "Belajar adalah kegiatan yang dilakukan oleh seseorang agar memiliki kompetensi berupa keterampilan dan pengetahuan yang diperlukan".

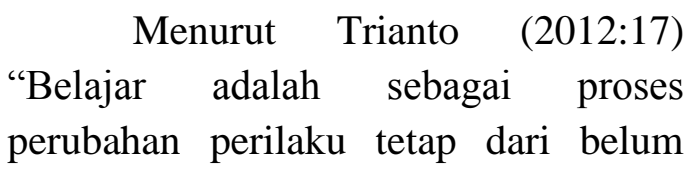

tahu menjadi tahu, dari tidak paham menjadi paham, dari kurang terampil menjadi terampil, dan dari kebiasaan lama menjadi kebiasaan baru, serta bermanfaat bagi lingkungan maupun individu itu sendiri". Proses belajar pada dasarnya dilakukan untuk meningkatkan kemampuan atau kompetensi personal.

Keberhasilan proses kegiatan pembelajaran, selain dipengaruhi oleh faktor guru juga dipengaruhi oleh faktor siswa itu sendiri. Di dalam proses pembelajaran, aktivitas siswa sangat diperlukan untuk melahirkan motivasi yang tinggi dan hasil belajar yang baik serta keingintahuan siswa terhadap materi pelajaran yang diberikan guru, agar siswa tersebut mampu melakukan berbagai kegiatan pembelajaran yang bersifat interaktif.

Kemudian Sanjaya (2008: 141) mengatakan "Keaktifan siswa itu ada yang secara langsung dapat diamati, seperti mengerjakan tugas, berdiskusi, mengumpulkan data dan lain sebagainya, akan tetapi ada juga yang tidak bisa diamati, seperti kegiatan mendengar, dan menyimak". Pembelajaran Berorientasi Aktivitas Siswa (PBAS) tidak hanya ditentukan oleh aktivitas fisik semata, akan tetapi juga ditentukan oleh aktivitas nonfisik seperti mental, intelektual, dan emosional.

Menurut Usman (2011: 22) aktivitas belajar siswa dapat digolongkan sebagai berikut:

1) Aktivitas visual (visual activities) seperti membaca, menulis, melakukan, eksperimen, dan demonstrasi. 
2) Aktivitas lisan (oral activities) seperti bercerita, membaca sajak, tanya jawab, diskusi, menyanyi.

3) Aktivitas mendengarkan (listening activities) seperti mendengarkan penjelasan guru, ceramah, pengarahan.

4) Aktivitas gerak (motor activities) seperti senam, atletik, menari, melukis.

5) Aktivitas menulis (writing activities) seperti mengarang, membuat makalah, membuat surat".

Aktivitas belajar siswa adalah rangkaian kegiatan yang dilakukan siswa dalam mengikuti pembelajaran sehingga menimbulkan perubahan perilaku belajar pada diri siswa, misalnya dari tidak tahu menjadi tahu atau dari tidak mampu melakukan kegiatan menjadi mampu melakukan kegiatan. Dengan kata lain siswa dituntut untuk aktif dalam menangkap atau menerima materi pelajaran dengan cara: aktif pada saat proses pembelajaran, aktif membaca ketika diberi kesempatan membaca, aktif mengacungkan tangan saat guru memberi pertanyaan, aktif memberikan pendapat ketika diberi kesempatan mengeluarkan pendapat, dan aktif bertanya ketika diberi kesempatan bertanya.

Dalam Kurikulum 2013, siswa yang memiliki kemampuan akademik di atas siswa lain diberi kesempatan untuk mendalami mata pelajaran yang diminatinya. Hal ini memberi kesempatan bagi siswa pada mata pelajaran tertentu dikelompok peminatannya, memiliki kemampuan dan prestasi tertentu sehingga penguasaan terhadap substansi mata pelajaran bersangkutan menjadi tumpuan bagi kelangsungan pendidikan pada jenjang yang lebih tinggi. Agar bakat, minat, dan kemampuan siswa terlayani maka salah satu kebijakan penting dalam Kurikulum 2013 adalah memberi kesempatan kepada siswa untuk memilih kelompok mata pelajaran peminatan yang diminati.

Pemilihan kelompok mata pelajaran tersebut dipilih siswa semenjak masuk ke SMA atau kelas $\mathrm{X}$ semester pertama, siswa boleh memilih kelompok mata pelajaran, yakni peminatan Matematika dan Ilmu Pengetahuan Alam, Ilmu-ilmu Sosial, atau Ilmu Bahasa dan Budaya. Kelompok mata pelajaran Ilmu-ilmu Sosial terdiri dari Geografi, Sejarah, Sosiologi dan Ekonomi (Permendikbud RI No. 69 Tahun 2013).

SMA Negeri 2 Padang merupakan SMA yang telah melaksanakan Kurikulum 2013 selama 4 tahun. Sebagai sekolah yang telah melaksanakan Kurikulum 2013, sekolah ini juga menerapkan kelompok mata pelajaran peminatan dan lintas minat. Menurut Peraturan Menteri Pendidikan dan Kebudayaan Republik Indonesia No. 69 Tahun 2013, “ Peminatan adalah suatu proses pengambilan pilihan dan keputusan oleh peserta didik tentang peminatan kelompok mata pelajaran, pendalaman mata pelajaran yang didasarkan atas pemahaman potensi diri dan peluang yang diselenggarakan pada satuan pendidikan". Kelompok mata pelajaran peminatan di SMA Negeri 2 Padang terdiri atas dua kelompok yaitu kelompok matematika dan ilmu pengetahuan alam (MIPA) dan ilmu- 
ilmu sosial (IIS). Kelompok peminatan yang dimaksud disini adalah siswa yang memilih program IIS (Ilmu-Ilmu Sosial).

Menurut Fadillah (2014:45) "Mata pelajaran pilihan lintas minat yaitu mata pelajaran yang dapat diambil oleh peserta didik di luar kelompok mata pelajaran peminatan yang dipilihnya. Untuk kelompok mata pelajaran lintas minat terdiri dari kelompok peminatan ilmu sosial bisa memilih lintas minatnya pelajaran fisika, biologi dan kimia, dan untuk kelompok peminatan ilmu alam bisa memilih lintas minatnya geografi, sosiologi dan ekonomi. Kelompok lintas minat yang dimaksud disini adalah siswa yang memilih program MIPA (Matematika dan Ilmu Pengetahuan Alam) yang mengambil mata pelajaran lintas minatnya yaitu geografi.

Menurut Sumaatmadja (2001:12), “Pembelajaran geografi adalah pembelajaran tentang aspekaspek keruangan permukaan bumi yang merupakan keseluruhan gejala alam dan kehidupan umat manusia dengan variasi kewilayahannya".

Pembelajaran geografi di sekolah menengah atas bertujuan untuk menumbuh kembangkan pengetahuan, keterampilan dan sikap terhadap fenomena geografis dalam konteks sosial, lingkungan dan kompleks wilayah. Oleh karena itu, di dalam kurikulum 2013 siswa dituntut untuk aktif selama proses pembelajaran terutama pada pembelajaran geografi. Idealnya siswa aktif dalam menangkap atau menerima pelajaran geografi yang diberikan oleh guru, serius mengikuti proses pembelajaran di sekolah, tidak terlambat memasuki kelas ketika pelajaran geografi dimulai, serta mempunyai keingintahuan yang tinggi terhadap materi pelajaran geografi yang diberikan guru dan siswa harus mempunyai hasil belajar yang baik.

Berdasarkan observasi yang dilakukan pada bulan Agustus 2017 di SMA Negeri 2 Padang, dalam proses pembelajaran geografi di kelas XI IIS dan MIPA, beberapa siswa kurang serius mengikuti proses pembelajaran di sekolah terlihat pada proses pembelajaran kelompok, siswa tersebut banyak mengobrol dengan temannya dan ribut saat proses pembelajaran, beberapa siswa terlambat memasuki kelas ketika pelajaran geografi dimulai, serta terlambat mengumpulkan tugas yang diberikan guru.

Aktivitas yang terjadi dalam proses pembelajaran merupakan keterlibatan diri siswa dalam bentuk sikap, pikiran dan perhatian. Aktivitas tersebut berguna untuk menunjang proses pembelajaran dan memperoleh manfaat dari kegiatan tersebut. Menurut Hamalik (2009:9) “Aktivitas adalah seperangkat kegiatan yang dilakukan oleh siswa dalam pembelajaran, misalnya kegiatan menulis, menggambar, dan kegiatan mental emosional". Kemudian menurut Sardiman (2010:95) "Aktivitas diperlukan dalam belajar karena pada prinsipnya belajar adalah berbuat untuk mengubah tingkah laku, tidak ada belajar kalau tidak ada aktivitas".

Selanjutnya menurut Djamarah (2010:38) "Aktivitas belajar dapat diartikan sebagai kemauan berbuat dan 
bekerja yang dilakukan untuk menghasilkan perubahan pengetahuan, nilai-nilai sikap, dan keterampilan pada siswa sebagai latihan yang dilaksanakan secara sengaja". Aktivitas belajar adalah kegiatan atau tindakan baik fisik maupun mental yang dilakukan oleh siswa untuk membangun pengetahuan dan keterampilan diri dalam kegiatan pembelajaran.

Berdasarkan uraian di atas tujuan penelitian ini adalah mengetahui perbandingan aktivitas belajar geografi antara siswa kelas XI kelompok peminatan dengan kelompok lintas minat di SMA Negeri 2 Padang.

\section{METODOLOGI PENELITIAN}

Jenis penelitian ini adalah penelitian deskriptif dengan pendekatan kuantitatif. Menurut Sugiyono (2012:14) "Penelitian deskriptif kuantitatif merupakan metode penelitian dengan memperoleh data yang berbentuk angka dianalisis sesuai dengan metode statistik yang digunakan kemudian diinterpretasikan".

Penelitian ini dilaksanakan di SMA Negeri 2 Padang dan waktu penelitian dilaksanakan pada semester ganjil tahun pelajaran 2017/2018.

Populasi dalam penelitian ini adalah seluruh siswa kelas XI kelompok peminatan dan lintas minat yang mengambil mata pelajaran geografi di SMA Negeri 2 Padang, berjumlah 130 orang siswa terdiri dari 60 orang siswa kelas XI kelompok peminatan dan 70 orang siswa kelas XI kelompok lintas minat. Sampel dalam penelitian ini diambil dengan menggunakan teknik purposive sampling, sehingga jumlah sampel dalam penelitian ini adalah 65 orang siswa terdiri dari 30 orang siswa kelompok peminatan dan 35 orang siswa kelompok lintas minat di SMA Negeri 2 Padang.

Teknik pengumpulan data dengan observasi, angket dan dokumentasi. Angket yang disebarkan kepada siswa telah diuji cobakan kemudian dilakukan uji validitas dan realibitasnya. Indikator yang digunakan dalam penelitian ini yaitu aktivitas visual, aktivitas lisan, aktivitas mendengar, aktivitas menulis dan aktivitas gerak.

Teknik analisis data yang digunakan adalah rumus statistik deskriptif dikemukakan oleh Sudjana (2006:129) yaitu:

$$
P=\frac{F}{N} \times 100 \%
$$

Keterangan : $\mathrm{P}=$ Presentase

$$
\begin{aligned}
& \mathrm{F}=\text { Frekuensi Responden } \\
& \mathrm{N}=\text { Jumlah Responden }
\end{aligned}
$$

Sedangkan

untuk pengkategorian nilai pencapaian aktivitas belajar digunakan klasifikasi sebagai berikut.

Tabel 1. Pengkategorian Nilai Pencapaian Aktivitas Belajar

\begin{tabular}{|c|c|c|}
\hline No & $\begin{array}{c}\text { Tingkat Pencapaian } \\
\text { Aktivitas Belajar }\end{array}$ & Kriteria \\
\hline 1 & $86 \%-100 \%$ & Sangat Aktif \\
\hline 2 & $71 \%-85 \%$ & Aktif \\
\hline 3 & $56 \%-70 \%$ & Cukup Aktif \\
\hline 4 & $0 \%-55 \%$ & Kurang Aktif \\
\hline
\end{tabular}

HASIL DAN PEMBAHASAN

Aktivitas Belajar Geografi Siswa Kelas XI Kelompok Peminatan di SMA Negeri 2 Padang

Aktivitas belajar geografi siswa kelas XI kelompok peminatan di SMA 
Negeri 2 Padang, dapat diketahui dari penyebaran angket ke 30 orang siswa dengan 30 item pernyataan terdiri dari gabungan lima indikator aktivitas belajar yaitu aktivitas visual, aktivitas lisan, aktivitas mendengar, aktivitas menulis dan aktivitas gerak. Berikut ini hasil data penelitian mengenai aktivitas belajar geografi siswa kelas XI kelompok peminatan di SMA Negeri 2 Padang.

Tabel 2. Aktivitas Belajar Geografi Siswa Kelas XI Kelompok Peminatan di SMA N 2 Padang

\begin{tabular}{|c|c|c|c|}
\hline No & Kriteria & $\begin{array}{c}\text { Frekuensi } \\
(\mathbf{F})\end{array}$ & $\begin{array}{c}\text { Persentase } \\
(\mathbf{\%})\end{array}$ \\
\hline 1 & Sangat Aktif & 0 & $0.00 \%$ \\
\hline 2 & Aktif & 10 & $33.33 \%$ \\
\hline 3 & Cukup Aktif & 18 & $60.00 \%$ \\
\hline 4 & Kurang Aktif & 2 & $6.67 \%$ \\
\hline \multicolumn{2}{|c|}{ Jumlah } & $\mathbf{3 0}$ & $\mathbf{1 0 0 . 0 0 \%}$ \\
\hline \multicolumn{2}{|c|}{ Rata-Rata } & \multicolumn{2}{|c|}{} \\
\hline
\end{tabular}

Sumber: Pengolahan Data Primer, 2017

Berdasarkan tabel di atas terdapat aktivitas belajar geografi siswa kelas XI kelompok peminatan di SMA Negeri 2 Padang, dari 30 orang siswa terdapat 10 orang siswa $(33.33 \%)$ memiliki aktivitas belajar geografi dengan kriteria aktif, hal ini menjelaskan bahwa dalam pembelajaran geografi, siswa aktif memperhatikan semua penjelasan tugas dan materi yang diberikan guru, dan sering membaca buku catatan maupun buku paket geografi pada waktu yang diberikan guru ketika belajar geografi, siswa aktif bertanya dan menjawab pertanyaan yang diberikan guru dan teman, siswa sering mendengarkan penjelasan guru mengenai materi pelajaran geografi, siswa sering mencatat materi pelajaran geografi, tidak pernah mengerjakan tugas mata pelajaran lain di dalam kelas selama proses pembelajaran geografi, serta siswa berani mempresentasikan materi pembelajaran geografi di depan kelas meskipun sedikit merasa gugup.

Kemudian 18 orang siswa (60.00\%) memiliki aktivitas belajar geografi dengan kategori cukup aktif, hal ini menjelaskan bahwa dalam pembelajaran geografi, siswa cukup aktif memperhatikan semua penjelasan tugas dan materi yang diberikan guru dan membaca buku catatan maupun buku paket geografi pada waktu yang diberikan guru, siswa cukup aktif bertanya dan menjawab pertanyaan yang diberikan guru dan teman, siswa cukup aktif mencatat materi pelajaran geografi, sering bermain HP dan keluar masuk selama proses pembelajaran geografi serta siswa kurang berani mempresentasikan materi pembelajaran geografi di depan kelas serta merasa gugup.

Selanjutnya terdapat 2 orang siswa (6.67\%) memiliki aktivitas belajar geografi dengan kriteria kurang aktif, hal ini menjelaskan dalam pembelajaran geografi, siswa kurang aktif memperhatikan penjelasan tugas dan materi yang diberikan guru, siswa tidak membaca materi pelajaran geografi apabila tidak diminta oleh guru dan sering membaca buku mata pelajaran lain selama pembelajaran geografi berlangsung, siswa kurang aktif bertanya dan menjawab pertanyaan yang diberikan guru dan teman, siswa sibuk berbicara dengan teman sebangku atau satu kelompok saat teman atau kelompok lain mempresentasikan hasil 
diskusinya di depan kelas, siswa kurang aktif mencatat materi pelajaran geografi, siswa lebih memilih berbicara dengan temannya dari pada mendengarkan penjelasan guru, selalu bermain HP dan keluar masuk selama proses pembelajaran geografi serta siswa tidak berani mempresentasikan materi pembelajaran geografi di depan kelas.

Dalam aktivitas belajar geografi siswa kelas XI kelompok peminatan di SMA Negeri 2 Padang, tidak ada siswa yang memiliki kriteria sangat aktif dalam proses pembelajara geografi.

\section{Aktivitas Belajar Geografi Siswa Kelas XI Kelompok Lintas Minat di SMA Negeri 2 Padang}

Aktivitas belajar geografi siswa kelas XI kelompok lintas minat di SMA Negeri 2 Padang, dapat diketahui dari penyebaran angket ke 35 orang siswa dengan 30 item pernyataan terdiri dari gabungan lima indikator aktivitas belajar yaitu aktivitas visual, aktivitas lisan, aktivitas mendengar, aktivitas menulis dan aktivitas gerak. Berikut ini hasil data penelitian mengenai aktivitas belajar geografi siswa kelas XI kelompok lintas minat di SMA Negeri 2 Padang.

Tabel 3. Aktivitas Belajar Geografi Siswa Kelas XI Kelompok Lintas Minat di SMA N 2 Padang

\begin{tabular}{|c|c|c|c|}
\hline No & Kriteria & $\begin{array}{c}\text { Frekuensi } \\
(\mathbf{F})\end{array}$ & $\begin{array}{c}\text { Persentase } \\
(\mathbf{\%})\end{array}$ \\
\hline 1 & Sangat Aktif & 6 & $17.14 \%$ \\
\hline 2 & Aktif & 22 & $62.86 \%$ \\
\hline 3 & Cukup Aktif & 7 & $20.00 \%$ \\
\hline 4 & Kurang Aktif & 0 & $0.00 \%$ \\
\hline \multicolumn{2}{|c|}{ Jumlah } & $\mathbf{3 5}$ & $\mathbf{1 0 0 . 0 0 \%}$ \\
\hline \multicolumn{2}{|c|}{ Rata-Rata } & \multicolumn{3}{|c|}{$\quad$} \\
\hline
\end{tabular}

Sumber: Pengolahan Data Primer, 2017
Berdasarkan tabel di atas terdapat, aktivitas belajar geografi siswa kelas XI kelompok lintas minat, dari 35 orang siswa terdapat 6 orang siswa (17.14\%) memiliki aktivitas belajar dengan kriteria sangat aktif, hal ini menjelaskan bahwa dalam pembelajaran geografi, siswa selalu membaca buku catatan maupun buku paket geografi, selalu memperhatikan semua penjelasan tugas dan materi yang diberikan guru, sangat aktif bertanya dan menjawab pertanyaan yang diberikan guru dan teman, serius mendengarkan penjelasan guru mengenai materi pelajaran geografi, selalu mencatat materi pelajaran geografi meskipun tanpa diminta atau dikumpulkan oleh guru, tidak pernah mengerjakan tugas mata pelajaran lain di dalam kelas selama belajar geografi, tidak pernah bermain HP dan keluar masuk selama pembelajaran geografi berlangsung, siswa selalu berani dan tidak pernah merasa gugup mempresentasikan materi pelajaran geografi.

Kemudian 22 orang siswa $(62.86 \%)$ memiliki aktivitas belajar dengan kriteria aktif, hal ini menjelaskan bahwa dalam pembelajaran geografi, siswa aktif memperhatikan semua penjelasan tugas dan materi yang diberikan guru, dan sering membaca buku catatan maupun buku paket geografi pada waktu yang diberikan guru ketika belajar geografi, siswa aktif bertanya dan menjawab pertanyaan yang diberikan guru dan teman, siswa sering mendengarkan penjelasan guru mengenai materi pelajaran geografi, siswa sering mencatat materi pelajaran geografi, tidak pernah mengerjakan 
tugas mata pelajaran lain di dalam kelas selama proses pembelajaran geografi, serta siswa berani mempresentasikan materi pembelajaran geografi di depan kelas meskipun sedikit merasa gugup.

Selanjutnya terdapat 7 orang siswa $(20.00 \%)$ memiliki aktivitas belajar dengan kriteria cukup aktif, hal ini menjelaskan bahwa dalam pembelajaran geografi, siswa cukup aktif memperhatikan semua penjelasan tugas dan materi yang diberikan guru dan membaca buku catatan maupun buku paket geografi pada waktu yang diberikan guru ketika belajar geografi, siswa cukup aktif bertanya dan menjawab pertanyaan yang diberikan guru dan teman, siswa cukup aktif mencatat materi pelajaran geografi, sering bermain HP dan keluar masuk selama proses pembelajaran geografi

Tabel 3. Perbandingan Aktivitas Belajar Geografi Antara Siswa Kelas XI Kelompok Peminatan dengan Lintas Minat di SMA N 2 Padang

\begin{tabular}{|l|c|c|c|c|}
\hline \multirow{2}{*}{ Aktivitas Belajar } & \multicolumn{2}{|c|}{ Peminatan (IIS) } & \multicolumn{2}{c|}{ Lintas Minat (MIPA) } \\
\cline { 2 - 5 } & $\begin{array}{c}\text { Persentase } \\
(\boldsymbol{\%})\end{array}$ & Kriteria & $\begin{array}{c}\text { Persentase } \\
(\boldsymbol{\%})\end{array}$ & Kriteria \\
\hline Aktivitas Visual & 66.94 & Cukup Aktif & 81.43 & Aktif \\
\hline Aktivitas Lisan & 75.71 & Aktif & 79.29 & Aktif \\
\hline Aktivitas Mendengar & 66.88 & Cukup Aktif & 68.93 & Cukup Aktif \\
\hline Aktivitas Menulis & 71.25 & Aktif & 77.14 & Aktif \\
\hline Aktivitas Gerak & 65.83 & Cukup Aktif & 76.02 & Aktif \\
\hline \multicolumn{1}{|c|}{ Rata-Rata } & $\mathbf{6 9 . 3 2}$ & Cukup Aktif & $\mathbf{7 6 . 5 6}$ & Aktif \\
\hline
\end{tabular}

Sumber: Pengolahan Data Primer, 2017

Berdasarkan tabel 3 di atas terdapat perbandingan aktivitas visual siswa kelas XI kelompok peminatan dengan kelompok lintas minat di SMA Negeri 2 Padang, siswa kelas XI kelompok peminatan memiliki rata-rata 66.94\% dengan kriteria cukup aktif, sedangkan siswa kelas XI kelompok lintas minat memiliki rata-rata $81.43 \%$ dengan kriteria aktif. Untuk serta siswa kurang berani mempresentasikan materi pembelajaran geografi di depan kelas serta merasa gugup.

Dalam aktivitas belajar geografi siswa kelas XI kelompok lintas minat di SMA Negeri 2 Padang, tidak ada siswa yang memiliki kriteria kurang aktif dalam proses pembelajaran geografi.

\section{Perbandingan Aktivitas Belajar Geografi antara Siswa Kelas XI Kelompok Peminatan dengan Kelompok Lintas Minat di SMA Negeri 2 Padang.}

Berdasarkan hasil pengolahan data tentang aktivitas belajar geografi siswa kelas XI kelompok peminatan dan kelompok lintas minat di SMA Negeri 2 Padang, diperoleh perbandingannya pada tabel 3 di bawah ini. 
sedangkan siswa kelas XI kelompok lintas minat sering memperhatikan saat guru menjelaskan materi dan tugas geografi di depan kelas, dan tidak ada siswa yang membaca buku mata pelajaran lain selama pembelajaran geografi berlangsung.

Perbandingan aktivitas lisan siswa kelas XI kelompok peminatan dengan kelompok lintas minat di SMA Negeri 2 Padang, yaitu siswa kelas XI kelompok peminatan memiliki rata-rata $75.71 \%$ dengan kriteria aktif, sedangkan siswa kelas XI kelompok lintas minat memiliki rata-rata $79.29 \%$ dengan kriteria aktif. Untuk membuktikan perbandingan aktivitas lisan tersebut, juga dilakukan observasi pada kegiatan pembelajaran geografi, siswa kelas XI kelompok peminatan dan kelompok lintas minat, siswa tersebut sering bertanya dan menjawab pertanyaan yang diberikan guru dan teman, siswa mengemukakan pendapat mengenai materi yang sedang dipelajari.

Perbandingan aktivitas mendengar siswa kelas XI kelompok peminatan dengan kelompok lintas minat di SMA Negeri 2 Padang, yaitu siswa kelas XI kelompok peminatan memiliki rata-rata $66.88 \%$ dengan kriteria cukup aktif, sedangkan siswa kelas XI kelompok lintas minat memiliki rata-rata $68.93 \%$ dengan kriteria cukup aktif. Untuk membuktikan perbandingan aktivitas mendengar tersebut, juga dilakukan observasi pada kegiatan pembelajaran geografi, siswa kelas XI kelompok peminatan dan kelompok lintas minat yaitu siswa kurang mendengarkan penjelasan materi yang diberikan guru dan temannya, siswa tersebut lebih memilih berbicara dan bercanda dengan teman sebangku saya dari pada mendengarkan penjelasan guru tersebut.

Perbandingan aktivitas menulis siswa kelas XI kelompok peminatan dengan kelompok lintas minat di SMA Negeri 2 Padang, yaitu siswa kelas XI kelompok peminatan memiliki rata-rata $71.26 \%$ dengan kriteria aktif, sedangkan siswa kelas XI kelompok lintas minat memiliki rata-rata $77.14 \%$ dengan kriteria aktif. Untuk membuktikan perbandingan aktivitas menulis tersebut, juga dilakukan observasi pada kegiatan pembelajaran geografi, siswa kelas XI kelompok peminatan dan kelompok lintas minat yaitu siswa mencatat materi pelajaran yang diberikan guru, membuat tugas yang diberikan guru.

Perbandingan aktivitas gerak siswa kelas XI kelompok peminatan dengan kelompok lintas minat di SMA Negeri 2 Padang, yaitu siswa kelas XI kelompok peminatan memiliki rata-rata 65.83\% dengan kriteria cukup aktif, sedangkan siswa kelas XI kelompok lintas minat memiliki rata-rata $76.02 \%$ dengan kriteria aktif. Untuk membuktikan perbandingan aktivitas gerak tersebut, juga dilakukan observasi pada kegiatan pembelajaran geografi, siswa kelas XI kelompok peminatan kurang berani mempresentasikan materi yang dipelajarinya di depan kelas, sering keluar masuk keluar-masuk kelas dan bermain HP selama proses pembelajaran geografi. Sedangkan siswa kelas XI kelompok lintas minat berani mempresentasikan materi yang dipelajarinya di depan kelas, tidak pernah keluar masuk keluar masuk 
kelas dan tidak bermain HP selama proses pembelajaran geografi.

Dengan demikian dapat disimpulkan perbandingan aktivitas belajar geografi antara siswa kelas XI kelompok peminatan dan kelompok lintas mintat di SMA Negeri 2 Padang, yaitu siswa kelas XI kelompok peminatan memiliki rata-rata tingkat pencapaian aktivitas belajar geografi 69.32\% dengan kriteria cukup aktif, sedangkan siswa kelas XI kelompok lintas minat memiliki rata-rata tingkat pencapaian aktivitas belajar geografi $76.56 \%$ dengan kriteria aktif. Jadi, siswa kelas XI kelompok peminatan memiliki aktivitas belajar geografi yang rendah dari pada siswa kelas XI kelompok lintas minat di SMA Negeri 2 Padang.

Menurut Peraturan Menteri

Pendidikan dan Kebudayaan Republik Indonesia No. 69 Tahun 2013, “ Peminatan adalah suatu proses pengambilan pilihan dan keputusan oleh peserta didik tentang peminatan kelompok mata pelajaran, pendalaman mata pelajaran yang didasarkan atas pemahaman potensi diri dan peluang yang diselenggarakan pada satuan pendidikan".

Sedangkan Lintas Minat Menurut Peraturan Menteri Pendidikan dan Kebudayaan Republik Indonesia No. 69 Tahun 2013, "Merupakan pengambilan pilihan dan memberi peluang kepada peserta didik untuk mempelajari mata pelajaran yang diminati namun tidak terdapat pada kelompok mata pelajaran peminatan".

Perbandingan aktivitas belajar siswa tersebut dapat disebabkan oleh faktor internal seperti aspek fisik yaitu fisik yang sehat akan mempengaruhi seluruh jaringan tubuh sehingga aktivitas belajar tidak rendah dan aspek psikologis yang mempengaruhi seseorang untuk melakukan aktivitas belajar adalah perhatian, pengamatan, tanggapan, ingatan, berfikir, dan bakat.

Kemudian faktor eksternal juga mempengaruhi akitivitas belajar seperti latar belakang siswa yang berbeda misalnya siswa kelompok peminatan berasal dari IIS sedangkan siswa kelompok lintas minat berasal dari MIPA sehingga dapat mempengaruhi tingkat aktivitas siswa dalam pembelajaran. Selanjutnya guru dan strategi mengajar dapat mempengaruhi aktivitas belajar yaitu bagaimana guru menyampaikan materi kepada siswa, strategi dan metode apa yang digunakan guru dalam pembelajaran mempengaruhi tinggi rendahnya aktivitas siswa dalam proses pembelajaran.

\section{PENUTUP \\ Kesimpulan}

Berdasarkan hasil penelitian dan pembahasan aktivitas belajar geografi siswa kelas XI kelompok peminatan dan kelompok lintas minat di SMA Negeri 2 Padang, maka dapat ditarik kesimpulan adalah: Aktivitas Belajar Geografi Siswa Kelas XI Kelompok Peminatan di SMA Negeri 2 Padang. Peminatan adalah program yang dipilih oleh peserta didik untuk memilih kelompok mata pelajaran sesuai dengan minat, bakat, dan kemampuan selama mengikuti pelajaran di SMA, pemilihan peminatan dilakukan atas dasar 
kebutuhan untuk melanjutkan keperguruan tinggi, terdapat $33.33 \%$ siswa yang aktif, $60.00 \%$ siswa yang cukup aktif, $6.67 \%$ siswa kurang aktif, dan tidak ada siswa yang memiliki kriteria sangat aktif dalam pembelajaran geografi.

Aktivitas Belajar Geografi Siswa Kelas XI Kelompok Lintas Minat di SMA Negeri 2 Padang. Kelompok lintas minat yaitu mata pelajaran yang dapat diambil oleh peserta didik di luar kelompok mata pelajaran peminatan yang dipilihnya, terdapat $17.14 \%$ siswa sangat aktif, $62.86 \%$ siswa aktif, $20.00 \%$ siswa cukup aktif, dan tidak ada siswa yang kurang aktif dalam pembelajaran geografi.

Perbandingan aktivitas belajar geografi antara siswa kelas XI kelompok peminatan dengan kelompok lintas minat di SMA Negeri 2 Padang yaitu siswa kelas XI kelompok peminatan memiliki kriteria cukup aktif dengan rata-rata $69.32 \%$, sedangkan siswa kelas XI kelompok lintas minat memiliki kriteria aktif dengan rata-rata $76.56 \%$. Siswa kelas XI kelompok peminatan memiliki aktivitas belajar geografi yang rendah dari pada siswa kelas XI kelompok lintas minat di SMA Negeri 2 Padang.

Saran

Berdasarkan hasil penelitian dan kesimpulan yang telah diuraikan, maka untuk meningkatkan aktivitas belajar geografi siswa kelas XI kelompok peminatan dan lintas minat di SMA Negeri 2 Padang menjadi lebih baik dimasa yang akan datang penulis menyarankan: Kepada siswa kelompok peminatan dan kelompok lintas minat di
SMA Negeri 2 Padang, diharapkan terus meningkatkan aktivitas belajarnya dengan cara memusatkan perhatian terhadap materi dan tugas-tugas belajar, lebih serius mendengarkan penjelasan guru mengenai materi pelajaran geografi, jangan keluar-masuk kelas selama proses pembelajaran geografi, serta berani mempresentasikan materi ketika ada kesempatan untuk tampil di depan kelas dalam proses pembelajaran.

Diharapkan kepada guru untuk menggunakan metode dan media pembelajaran yang bervariasi agar lebih dapat meningkatkan aktivitas siswa dalam proses pembelajaran. Diharapkan kepada pihak sekolah untuk lebih memperhatikan kebutuhan siswa dan menyediakan berbagai fasilitas dalam belajar agar lebih dapat meningkatkan aktivitas belajar siswa dalam proses pembelajaran.

\section{DAFTAR PUSTAKA}

Djamarah, Syaiful Bahri. 2010. Guru dan Anak dalam Interaksi Edukatif. Jakarta: Rineka Cipta

Fadillah. M. 2014. Implementasi Kurikulum 2013 dalam Pembelajaran SD/MI, SMP/MTs, \& SMA/MA. Yogyakarta: Ar-Ruzz Media

Hamalik, Oemar. 2009. Proses Belajar Mengajar. Jakarta: Bumi Aksara

Peraturan Menteri Pendidikan dan Kebudayaan Republik Indonesia No. 69 Tahun 2013 tentang Kerangka Dasar dan Struktur Kurikulum Sekolah Menengah Atas/Madrasah Aliyah

Permendikbud Nomor 22 Tahun 2016 tentang Standar Proses Pendidikan Dasar dan Menengah 
Pribadi, Benny A. 2011. Model Desain

Sistem Pembelajaran. Jakarta:

Dian Rakyat

Sanjaya, Wina. 2008. Strategi

Pembelajaran Berorientasi

Standar Proses Pendidikan.

Jakarta: Kencana

Sardiman. A.M. 2010. Interaksi dan Motivasi Belajar Mengajar. Jakarta: Rajawali Pers

Sudjana, Nana. 2006. Tuntunan Penyusunan Karya Ilmiah. Bandung: Sinar Baru

Sugiyono. 2012. Metode Penelitian Pendidikan Pendekatan

Kuantitatif, Kualitatif, dan $R \& D$. Bandung : Alfabeta

Sumaatmadja, Nursyid. 2001. Metodologi Pengajaran

Geografi. Jakarta: Bumi Aksara

Trianto. 2012. Model Pembelajaran

Terpadu. Jakarta: Bumi Aksara

Undang-Undang Republik Indonesia Nomor 20 Tahun 2003 tentang Sistem Pendidikan Nasional

Usman, Moh Uzer. 2011. Menjadi Guru

Profesional. Jakarta : Erlangga 